\title{
Genetic affinities of Helicobacter pylori isolates from ethnic Arabs in Kuwait
}

\author{
M John Albert ${ }^{* 1}$, Hanan M Al-Akbal1', Rita Dhar², De Ronita ${ }^{3}$ and Asish K Mukhopadhyay ${ }^{3}$
}

\begin{abstract}
Helicobacter pylori is one of the most genetically diverse of bacterial species, and since the $5^{\prime}$-end of cagA gene and the middle allele of vacA gene of $\mathrm{H}$. pylori from different populations exhibit considerable polymorphisms, these sequence diversities were used to gain insights into the genetic affinities of this gastric pathogen from different populations. Because the genetic affinity of Arab strains from the Arabian Gulf is not known, we carried out genetic analysis based on sequence diversities of the cagA and the vacA genes of $\mathrm{H}$. pylori from 9 ethnic Arabs in Kuwait. The analysis showed that the Kuwaiti isolates are closely related to the Indo-European group of strains, although some strains have a tendency to form a separate cluster close to the Indo- European group, but clearly distinct from East Asian strains. However, these results need to be confirmed by analyses of neutral markers (house-keeping genes in a multi-locus sequence typing [MLST]) platform. The profiling of virulence-associated genes may have resulted from ecologically distinct populations due to human migration and geographical separation over long periods of time.
\end{abstract}

\section{Findings}

Helicobacter pylori, the Gram-negative, spiral, microaerobic bacterium, infects more than half of the world's population [1]. It is a major cause of gastritis and peptic ulcer disease, and a risk factor for gastric adenocarcinoma and mucosa-associated lymphoid tissue lymphoma [2]. There is extraordinary diversity among $H$. pylori strains as evident by DNA fingerprinting [3]. This diversity has been enhanced by extensive interstrain gene transfer and recombination $[4,5]$. In contrast, much stronger clonality, with the predominance of relatively fewer clones, is seen in populations of several other much-studied bacterial species [6,7]. The great diversity among $H$. pylori strains implies a striking lack of selection for just one or a few genotypes that might be best adapted for all humans.

The virulence associated $\operatorname{cag} A$, and $v a c A$ genes provide examples in which evolutionary dynamics are likely to have been shaped by local differences in host physiology. CagA and VacA proteins each enter target cells and affect several normal cellular signal transduction pathways, with strengths and specificities that vary geographically.

The sequence diversities at the 5 '-end of the cagA gene and the mid-region alleles of the $v a c A$ gene have been

\footnotetext{
* Correspondence: john@hsc.edu.kw

${ }^{1}$ Department of Microbiology, Faculty of Medicine, Kuwait University, Jabriya, Kuwait

Full list of author information is available at the end of the article
}

used to deduce the genetic relationships among strains from East Asia, South Asia, South America, Africa, Europe and USA $[8,9]$. However, there are no data on the genetic affinity of Arab strains from the Arabian Gulf Region including those from Kuwait, although some data exist on their genotypes $[10,11]$. In the current study, we analysed the genetic relationship of Kuwaiti strains with strains from other ethnic world populations. In order to investigate the gene pool diversity of Kuwaiti isolates of H. pylori, we sequenced putative virulence genes cag $A$ and $v a c A$, whose allele frequency have been shown to vary by ethnic group [12].

H. pylori isolates were cultured from the gastric biopsies of dyspeptic ethnic Arab Kuwaiti patients in a previous study on antibiotic susceptibility conducted during 2003-2005 [13]. The isolates were stored in brain heart infusion broth (Difco Laboratories, Detroit, Michigan, USA) with $15 \%$ glycerol at $-70^{\circ} \mathrm{C}$. The isolates were grown microaerobically on brain heart infusion agar supplemented with sheep blood, IsoVitalex and Dent supplement as described previously [13]. Chromosomal DNA was extracted by the CTAB (hexadecyl-trimethyl ammonium bromide) method [13] from culture derived from a single colony. A $219 \mathrm{bp}$ fragment from the 5 -end of the cagA was amplified by PCR with the primers, cagA 5 and cagA2 [9]. PCR was carried out in a 50- $\mu$ l volume using $10 \mathrm{ng}$ DNA, $25 \mu \mathrm{l}$ of HotStarTaq Master Mix (catalogue 
number 203445, Qiagen, Valencia, California, USA), 10 pmol of each primer, for 40 cycles using the following conditions: $95^{\circ} \mathrm{C}$ for $60 \mathrm{~s}, 55^{\circ} \mathrm{C}$ for $60 \mathrm{~s}$, and $72^{\circ} \mathrm{C}$ for $90 \mathrm{~s}$. A $700 \mathrm{bp}$ middle region of the $v a c A$ gene was amplified with the primers, VAm-F and VAm-R [9]. The concentrations of various PCR components were the same as in the cagA PCR, but amplification was done in 32 cycles with the following conditions: $94^{\circ} \mathrm{C}$ for $40 \mathrm{~s}, 55^{\circ} \mathrm{C}$ for $40 \mathrm{~s}$, and $72^{\circ} \mathrm{C}$ for $70 \mathrm{~s}$. The $\mathrm{m} 1$ (567 bp) or $\mathrm{m} 2$ (642 bp) allele of the middle region of the $v a c A$ gene was determined by PCR with the primers, VAG-F and VAG-R [14]. The concentration of PCR ingredients were the same as the other two PCRs above, but amplification was done in 35 cycles with the following conditions: $94^{\circ} \mathrm{C}$ for $60 \mathrm{~s}, 55^{\circ} \mathrm{C}$ for $60 \mathrm{~s}$, and $72^{\circ} \mathrm{C}$ for $60 \mathrm{~s}$. The PCR products were visualised by agarose gel electrophoresis after staining with ethidium bromide and examination under ultraviolet light. The PCR products were purified by High Pure PCR product purification kit (Roche Diagnostics, Indianapolis, Indiana, USA) according to manufacturer's instructions and directly sequenced. DNA sequencing was performed by the dideoxynucleotide chain termination method with an ABI PRISM BigDye Termination Cycle Sequencing Ready Reaction kit (Perkin-Elmer-Applied Biosystems, Forster City, California, USA) in an ABI PRISM automated sequencer. The DNA sequences were manually edited and compared with the selected sequences in the public database http://www.ncbi.nlm.nih.gov/nucleotide/ with the PHYLIP programme of J. Felsenstein http://evolution genetics.washington.edu/phylip.html[15]. The genetic trees were generated using DDBJ programme http:// www.ddbj.nig.ac.jp and visualised using Treeview programme (version1.61; http://taxonomy.zoology.gla.a c.uk/rod/treeview.html). The lengths of the cagA gene and the $v a c A$ gene used in the analyses were $209 \mathrm{bp}$ and $620 \mathrm{bp}$ (from the $700 \mathrm{bp}$ amplified region) respectively.

In the previous study on the antibiotic susceptibility of $H$. pylori strains conducted in Al-Adan Hospital in Kuwait, cultures were available from 39 ethnic Arab Kuwaiti patients [13]. Of these cultures, 16 were amplified by the $\operatorname{cag} A$ gene primers, 21 by the $v a c A$ gene primers and 9 by primers for both the genes. Our study attempted to analyze the genomes of the 9 Kuwaiti isolates in defining the evolutionary history of these strains. The isolate numbers are: $7,16,21,46,202,220,43,25$, and 42675 . The sequence obtained during this study have been assigned the following accession numbers [GenBank:GU212658 to GenBank:GU212666] (cagA 5'-end), [GenBank:GU212667 to GenBank:GU212669 and GenBank:GU441847] (vacA m1 allele) and [GenBank:GU441 844, GenBank:GU441846, GenBank:GU441848 to GenBank:GU441850] (vacA m2 allele).

To assess the genetic relationship between the strains isolated from Kuwait and those from other regions, we focused first on a segment near the 5 ' end of the cagA gene that had been used to distinguish East Asian and European strains [16]. This segment was amplified by PCR from nine Kuwaiti strains and sequenced directly. The sequences obtained were closely related to one another (97-99\% match) and also to those from Western strains (91-99\% DNA sequence match), essentially the Indo-European cluster, but only $77-86 \%$ related to those from Chinese and Japanese (East Asian) strains (Fig. 1). It was of interest to note that among the nine strains analysed from Kuwait, four of them (strains 7, 16, 202 and 42675) formed a somewhat separate cluster and were closely related to one another (99-100\% match). These 4 strains were $92-93 \%$ related to the rest five Kuwaiti strains. Formal classification of these strains would require analysis from a larger number of strains from this region. DNA sequencing analysis of a $0.7-\mathrm{kb}$ PCR fragment containing the $v a c A$ middle region from various parts of the world revealed the existence of 3 distinct groups (Fig. 2). The sequence analysis result showed that Kuwaiti isolates were $86-96 \%$ related to one another. Among the three isolates, one isolate (strain 43) was closely related to (96-99\% match) Indian cluster, while the other two isolates (strain 46 and strain 4675) were 93-95\% related to ethnic European strains and were $85-86 \%$ related to the East Asian cluster. This shows that strains isolated from Kuwait have an mixed gene pool. However, genetic analysis of the other five strains with vacAm2 genotype showed that they were much more scattered and related to the strains from Germany and India, even though the strain 25 was somewhat distant in contrast to the East Asian strains, which were much more congruent (Fig. 3).

$\operatorname{cag} A$ and $v a c A$ genes are virulence genes under selective pressure and hence subjected to sequence variation. Therefore, the data presented in this study need to be confirmed by sequence analyses of neutral genes such as house-keeping genes used in multi-locus sequence typing (MLST). Such analyses have been carried out for H. pylori isolates from various ethnic groups in India [17] and Iran [18]. These studies showed that isolates in these countries essentially belonged to the population of hpEurope, though isolates from various ethnic groups belonged to distinct subpopulation groups. Also, our conclusion of mixed gene in Kuwaiti isolates should be confirmed by Bayesian statistics.

The Arab population in the Middle East is a distinct ethnic race. Although the region is geographically separate, it established contacts with other regions of the world through colonisation and trade hundreds of years ago. Our study has shown that the strains that infect ethnic Arab Kuwaiti population is closely related to the Indo-European strains although some strains have a tendency to form a separate cluster close to the Indo- Euro- 


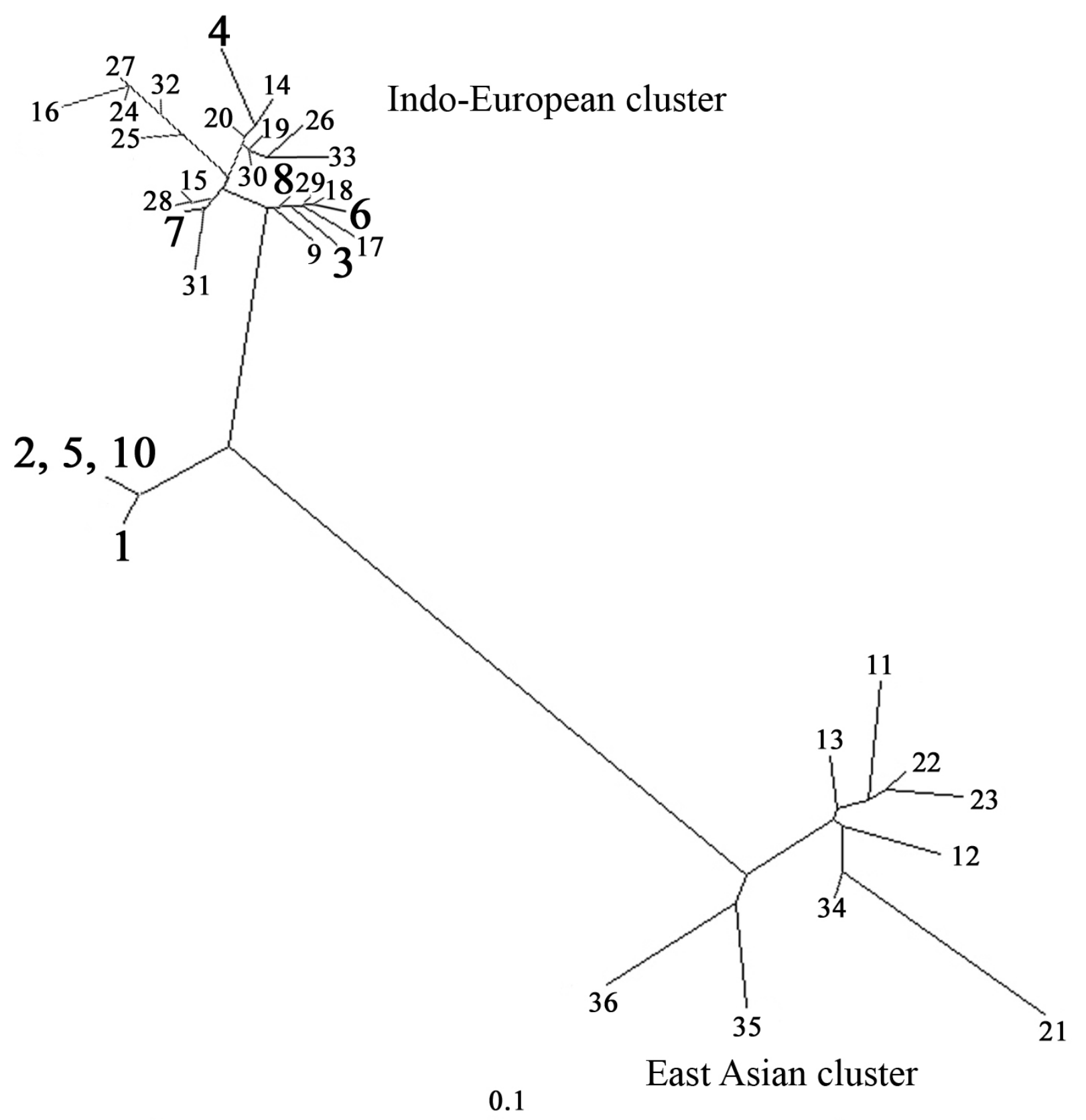

Figure 1 Genetic tree based on an informative 209 bp segment at the 5 ' end of cagA of $H$.pylori strains determined in this study (test strains 1-8 and 10) or reported by others. The test strains determined in this study are marked in black bold face. Sequences other than those for the test strains are from public database, as indicated. The tree was generated using DDBJ programme. Each number in this figure indicates the cagA gene sequence from a given strain, as follows (GenBank accession numbers in parentheses). The strains used are as follows. 1.7 [GU212660], 2. 16 [GU212663], 3. 21 [GU212661], 4. 46 [GU212658], 5. 202 [GU212659], 6. 220 [GU212664], 7. 43 [GU212666], 8. 25 [GU212665], 9. 26695 (Britain) [NC 000915], 10. 42675 [GU212662], 11. ChinaR27 [AJ252979]; 12 ChinaR40 [AJ252982]; 13. ChinaR47 [AJ252985]; 14. Dutch79 [AJ252970]; 15. Dutch107 [AJ252963]; 16. Dutch161A [AJ252965]; 17. Dutch292 [AJ252971]; 18. Dutch419 [AJ252974]; 19. Gambia4659 [AF198468]; 20. Gambia 4797[AF198469]; 21. Hongkong77 [AF198485]; 22. Hongkong81 [AF198486]; 23. Hongkong97_42 [AJ239733]; 24. India3 [AF202219]; 25. India10 [AF202222]; 26. India18 [AF202224]; 27. India19[AF202225]; 28. Lithuania5_1 [AJ239734]; 29. Peru2B [AF198474]; 30. Peru4A [AF198477]; 31. Peru8C [AF198478]; 32. Peru24C [AF198473]; 33. Peru35B [AF198476]; 34. Thailand88-28 [AJ239722]; 35. JapanGC4 [AF198484]; 36. JapanF32 [AJ239726]. 


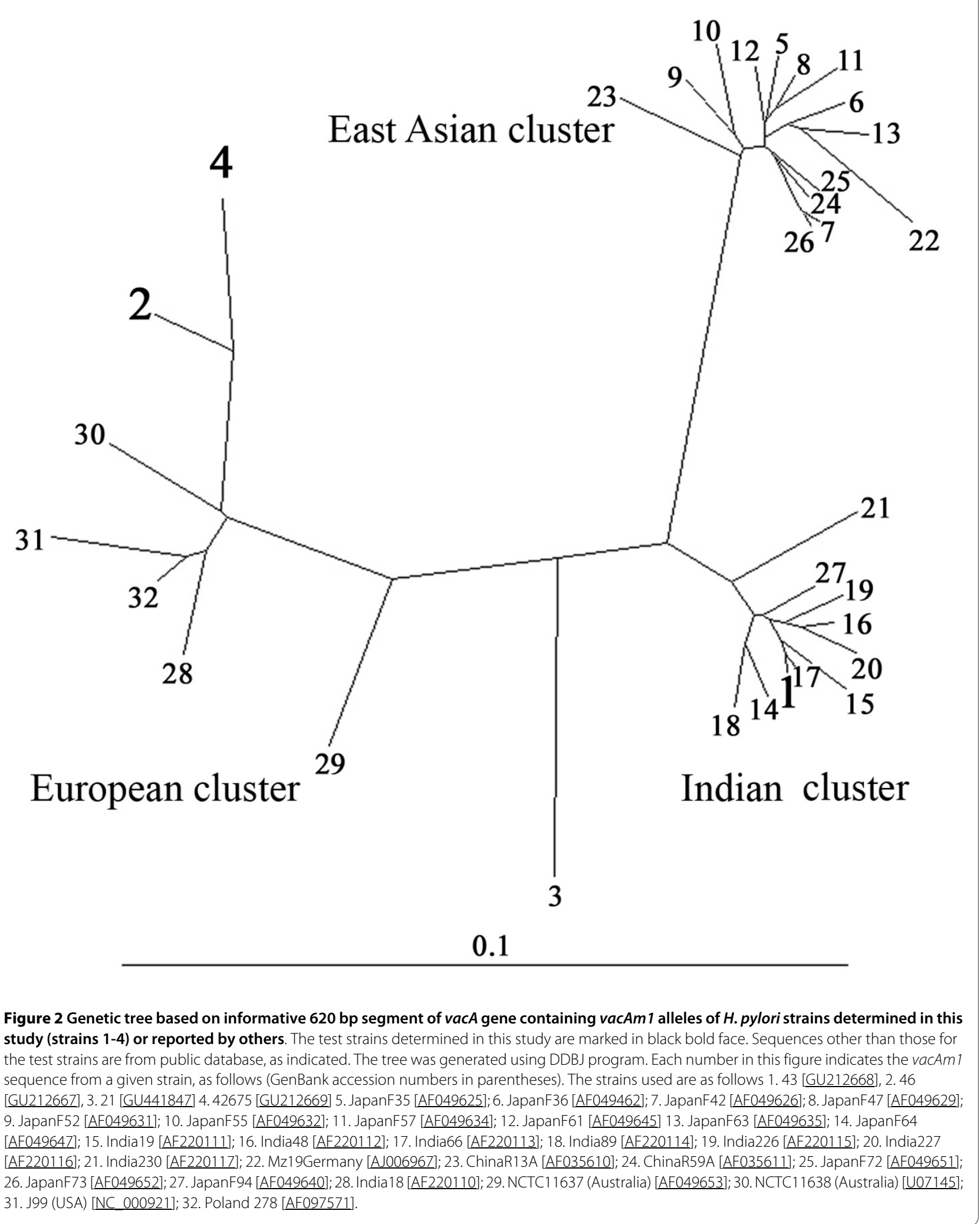




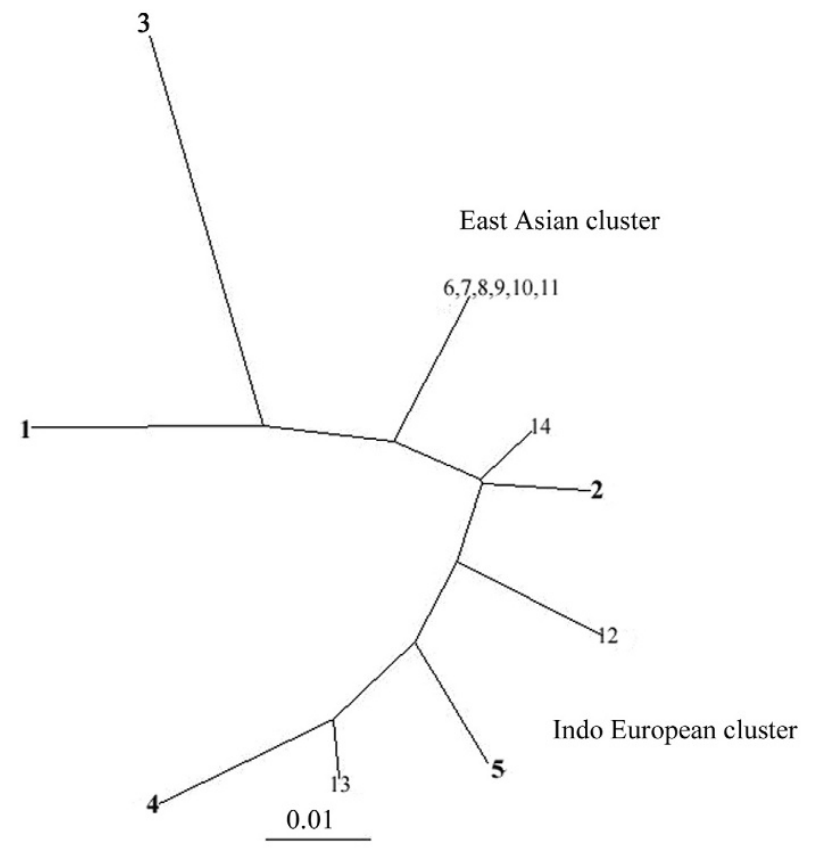

Figure 3 Genetic tree based on an informative 620 bp segment of vacA gene containing vacAm2 alleles of $H$. pylori strains determined in this study (strains 1-5) or reported by others. The test strains determined in this study are marked in black bold face. Sequences other than those for the test strains are from public database, as indicated. The tree was generated using DDBJ programme. Each number in this figure indicates the vacAm2 sequence from a given strain, as follows (GenBank accession numbers in parentheses). The strains used are as follows 1.7 [GU441846] 2.16 [GU441848] 3.25 [GU441849] 4.202 [GU441844] 5.220 [GU441850] 6. JapanOK160 [AB190979] 7. JapanOK204 [AB190986] 8. JapanOK205 [AB190987)] 9. JapanOK210 [AB190988] 10. JapanOK129 [AB190972] 11. JapanOK181 [AB190982] 12. GermanyMz28a [AJ006969] 13. GermanyMz26a [AJ006968] 14. India90 [AF220119].

pean group but far away from East Asian strains. This suggests a common ancestry of strains circulating in Kuwait, India and the European countries. The ancestry of these strains is different from that of the strains circulating in the Far East since they formed a distinct cluster. Human migration and geographical separation over long periods of time may have resulted in ecologically distinct populations of $\mathrm{H}$. pylori infecting individuals in different continents. The profiling of virulence-associated genes like cagA and vacA provide examples in which evolutionary dynamics might have been shaped by local differences in environmental conditions and host physiology and may have resulted in ecologically distinct populations due to human migration and geographical separation over long periods of time. The remarkable differences found to-date between various Asian and European H. pylori populations in at least a few loci along with the present data from Kuwaiti strains should encourage further analyses of strains from relatively understudied geographic areas and human ethnic groups like Middle Eastern regions where human migration and geographical separation over long periods of time are prominent. Such "geographic genomics" may unearth new genes that affect human infection, increase our understanding of bacterium-host interactions in colonisation and disease, and impart new insights into the evolution of this diverse and globally distributed human pathogen.

\section{Competing interests}

The authors declare that they have no competing interests.

\section{Authors' contributions}

MJA and AKM conceived the study and drafted the manuscript. HMA, RD and RoD carried out the work. All authors read the manuscript and approved the final draft.

\section{Acknowledgements}

None.

\section{Author Details}

'Department of Microbiology, Faculty of Medicine, Kuwait University, Jabriya, Kuwait, 2Microbiology Laboratory, Farwaniya Hospital, Farwaniya, Kuwait and ${ }^{3}$ National Institute of Cholera and Enteric Diseases, Calcutta, India

Received: 21 June 2010 Accepted: 5 July 2010

Published: 5 July 2010

\section{References}

1. Parsonnet J: Incidence of Helicobacter pylori infection. Aliment Pharmacol Ther 1995, 9:45-51.

2. Dunn BE, Cohen H, Blaser MJ: Helicobacter pylori. Clin Microbiol Rev 1997, 40:720-741 
3. Akopyanz N, Bukanov NO, Westblom TU, Berg DE: DNA diversity among clinical isolates of Helicobacter pylori detected by PCR-based RAPD fingerprinting. Nucleic Acids Res 1992, 20:5137-5142.

4. Kersulyte D, Chalkauskas H, Berg DE: Emergence of recombinant strains of Helicobacter pylori during human infection. Mol Microbiol 1999 31:31-43.

5. Suerbaum S, Maynard Smith J, Bapumia K, Morelli G, Smith NH, Kuntsmann E, Dyrek I, Achtman M: Free recombination within Helicobacter pylori. Proc Natl Acad Sci USA 1998 1998, 95:12619-12624.

6. Smith JM, Smith NH, O'Rourke M, Spratt BG: How clonal are bacteria? Proc Natl Acad Sci USA 1993, 90:4384-4388.

7. Feil EJ, Maiden MC, Achtman M, Spratt BG: The relative contributions of recombination and mutation to the divergence of clones of Neisseria meningitidis. Mol Biol Evol 1999, 16:1496-1502.

8. Mukhopadhyay AK, Kersulyte D, Jeong JY, Datta S, Ito Y, Chowdhury S, Santra A, Bhattacharya SK, Azuma T, Nair GB, Berg DE: Distinctiveness of genotypes of Helicobacter pylori in Calcutta, India. J Bacteriol 2000, 182:3219-3227.

9. Rahman M, Mukhopadhyay AK, Nahar S, Datta S, Ahmad MM, Sarker S, Masud IM, Engstrand L, Albert MJ, Nair GB, Berg DE: DNA-level characterization of Helicobacter pylori strains from patients with overt disease and with benign infections in Bangladesh. J Clin Microbio/ 2003, 41:2008-2014

10. Al Qabandi A, Mustafa AS, Siddique I, Khajah AK, Madda JP, Junaid TA: Distribution of vacA and cagA genotypes of Helicobacter pylori in Kuwait. Acta Trop 2005, 93:283-288.

11. Momenah AM, Tayeb MT: Helicobacter pylori cagA and iceA genotypes status and risk of peptic ulcer in Saudi patients. Saudi Med J 2007 28:382-385

12. Kersulyte D, Mukhopadhyay AK, Velapatin OB, Su W, Pan Z, Garcia C, Hernandez V, Valdez Y, Mistry RS, Gilman RH, Yuan Y, Gao H, Alarco'n T, Lo'pez-Brea M, Nair GB, Chowdhury A, Datta S, Shirai M, Nakazawa T, Ally R, Segal I, Wong BCY, Lam SK, Olfat FO, Bore'n T, Engstrand L, Torres O, Schneider R, Thomas JE, Czinn S, Berg DE: Differences in genotypes of Helicobacter pylori from different human populations. J Bacteriol 2000, 182:3210-3218.

13. Albert MJ, Al-Mekhaizeem K, Neil L, Dhar R, Dhar PM, Al-Ali M, Al-Abkal $H M$, Haridas S: High prevalence and level of resistance to metronidazole, but lack of resistance to other antimicrobials in Helicobacter pylori, isolated from a multiracial population in Kuwait. Aliment Pharmacol Ther 2006, 24:1359-1366.

14. Chattopadhyay S, Patra R, Ramamurthy T, Chowdhury A, Santra A, Dhali GK, Bhattacharya SK, Berg DE, Nair GB, Mukhopadhyay AK: Multiplex PCR assay for rapid detection and genotyping of Helicobacter pylori directly from biopsy specimens. J Clin Microbiol 2004, 42:2821-2824.

15. Tomb JF, White O, Kerlavage AR, Clayton RA, Sutton GG, Fleischmann RD, Ketchum KA, Klenk HP, Gill S, Dougherty BA, Nelson K, Quackenbush J, Zhou L, Kirkness EF, Peterson S, Loftus B, Richardson D, Dodson R, Khalak HG, Glodek A, McKenney K, Fitzegerald LM, Lee N, Adams MD, Hickey EK, Berg DE, Gocayne JD, Utterback TR, Peterson JD, Kelley JM, Cotton MD, Weidman JM, Fujii C, Bowman C, Watthey L, Wallin E, Hayes WS, Borodovsky M, Karp PD, Smith HO, Fraser CM, Venter JC: The complete genome sequence of the gastric pathogen Helicobacter pylori. Nature 1997, 388:539-547.

16. van der Ende A, Pan ZJ, Bart A, van der Hulst RW, Feller M, Xiao SD, Tytgat GN, Dankert J: cagA-positive Helicobacter pylori populations in China and The Netherlands are distinct. Infect Immun 1998, 66:1822-1826.

17. Devi SM, Ahmed I, Francalacci P, Hussain MA, Akhter Y, Alvi A, Sechi LA, Megraud F, Ahmed N: Ancestral European roots of Helicobacter pylori in India. BMC Genomics 2007, 8:184

18. Latifi-Navid S, Ghorashi SA, Siavoshi F, Linz B, Massarrat S, Khegay T, Salmanian A-H, Shayesteh AA, Masoodi M, Ghanadi K, Ganji A, Suerbaum S, Achtman M, Malekzadeh R, Falush D: Ethnic and geographic differentiation of Helicobacter pylori within Iran. PLOS ONE 2010, 5:e9645.

doi: 10.1186/1757-4749-2-6

Cite this article as: Albert et al., Genetic affinities of Helicobacter pylori isolates from ethnic Arabs in Kuwait Gut Pathogens 2010, 2:6

\section{Submit your next manuscript to BioMed Central} and take full advantage of:

- Convenient online submission

- Thorough peer review

- No space constraints or color figure charges

- Immediate publication on acceptance

- Inclusion in PubMed, CAS, Scopus and Google Scholar

- Research which is freely available for redistribution 